\title{
Burnout Syndrome in Community Health Agents: an Integrative Review

\begin{abstract}
Thaís Dandara Azevedo da Silva1, Hebe Janayna Mota Duarte Beserra2, Maurício Caxias de Souza ${ }^{3}$, Sérgio Ribeiro dos Santos ${ }^{4}$, Ericka Silva Holmes ${ }^{5}$, Rayanne Santos Alves ${ }^{5}$ Wilma Dias Fontes Pereira ${ }^{6}$, Aurilene Josefa Cartaxo Gomes de Arruda ${ }^{6}$, Jackeline Abílio de Souza ${ }^{5}$, Leila de Cássia Tavares da Fonseca ${ }^{6}$, Maria Bernadete de Sousa Costa ${ }^{6}$ Laura Cristhiane Mendonça Rezende Chaves ${ }^{7}$, Juliana Barbosa Medeiros ${ }^{8}$, Gerson da Silva Ribeiro ${ }^{6}$, Jessyka Cibelly Minervina da Costa Silva ${ }^{9}$, Luciara Cristina Ferreira Dos Santos ${ }^{7}$
\end{abstract}

\section{Abstract}

Objective: Analyze the Burnout Syndrome on Health Community Agents in the nursing context, based on online periodicals.

Method: We have addressed an integral revision of the literature. The data was collected between March and October of 2015 on the LILACS and BDENF databases.

Results: 6 articles were composed with this study samples, emerging into the development of two thematic categories: 1) ACS ways of sickness; 2) Confront strategies by the Health Community Agents.

Conclusion: The forms of sickness experienced by the agents cannot be modified or avoided since they represent essential aspects of this professional performance. In order to face this problem, it seems to exist an unfamiliarity, by this professional category, of the large number of activities that can be developed with the objective of decreasing the stress of the work process.
1 Nurse. Graduated by the Mauricio de Nassau College. João Pessoa, Brazil.

2 Nurse. Master in human health and environment by the Pernambuco Federal University. UFPE. Recife, Brazil.

3 Nurse. Member of the Study and Research Group in Management and Medical Informatics of the Federal University of Paraíba. UFPB. João Pessoa, Brazil.

4 Nurse. Doctor in Sociolgy. Titular teacher Departament of Clinical Nursing UFPB. Teacher of Graduate Program in Health Decision Models. GEPAIE Leader. João Pessoa, Brazil.

5 Nurse. Doctoral student program in Decision Models, Federal University of Paraíba. UFPB. João Pessoa, Brazil.

6 Departament of Clininal Nursing at the Federal University of Paraíba. João Pessoa, Brazil.

7 Master of Nursing. Federal University of Paraiba. João Pessoa, Brazil.

8 Nurse. Specialist in Chronic Diseases noncommunicable. MSc in Public Health from UEPB. João Pessoa, Brazil.

9 Nurse. Graduate at the Federal University of Paraíba. João Pessoa, Brazil.

Contact information:

Maurício Caxias de Souza.

झ mauriciocaxias_@hotmail.com

Keywords

Burnout; Health Community

Agent; Nursing. 


\section{Introdution}

The great socio-cultural, economic and political changes in recent years in search of adaptations to stress factors, by society, it has passed in the sphere of labor. In the capitalist system there is a tireless worker search for multifunctionality and the qualification to perform various activities [1, 2]. Such changes have brought about change, the negative point of view, affecting the worker's well-being during their work process and everyday life [3].

The growing economic and social changes also brought interference in workers' health causing symptoms such as: anxiety, insomnia, anxiety, loss of appetite or increased food intake in the main meals of the day, body aches, fatigue and other problems [4].

The interaction of human beings with different forms of work can lead to diseases arising from physical, emotional, biological elements and the organization of work itself [5]. Among these, the Burnout Syndrome (SB) is a response to prolonged stress and has negative consequences in social, work and family. In the labor market, the consequences are revealed in the lack of productivity, absenteeism and incidents of accidents [6].

The term Burnout in portuguese means burnout began to be pronounced in the United States in the 1970s Since then, this phenomenon began to have greater prominence among researchers, particularly in matters related to professionals in direct contact with the public. Thus, these professionals need to be given attention to your health, since the stressors arising from interpersonal relationships at work every day trigger psychic order problems [7].

In this context, there is the profession of Community Health Agent (ACS) category regulated by Law $n^{\circ}$ 11.350, of 5 October 2006. As a member of the multidisciplinary team of the Family Health Strategy, the ACS has a unique role to be the link between the community, the territory and the professionals of the Family Health Unit (USF). The working process of this category involves planning, promotion, recovery of health and prevention of diseases and disorders; health surveillance actions; records and monitoring the health situation of households in their micro area of operation; health education people belonging to the territory of their responsibility $[8,9]$.

Despite having defined and limited activities to be performed, the ACS experiencing difficulties related to the lack of resolution of the problems identified in the community; the episodes of conflict with other professionals of the multidisciplinary team; the failure in the ordinations of services provided by USF; and the high demand for people accompanied by ACS. Because they live in the same area of expertise these professionals also report challenges related to living with problems, sometimes social, political, economic and cultural, faced by users [10].

Due to the factors listed above, the ACS can develop a mental and physical exhaustion and mental disorders with behavioral changes, such as burnout syndrome [11]. In this context, it is essential to develop coping strategies and prevention of diseases that have the potential to affect a worker's health. Considering the risk factors present in the work of health professionals, we sought to answer the following question: What factors identified in the scientific literature, ACS predispose to the development of SB and what coping strategies? Therefore, the present study was to investigate, based on online journals, the Burnout Syndrome in community health agents of the Family Health Strategy.

\section{Method}

It is a study of the type integrative literature review, which sought to integrate and condense research findings on SB in ACS, in a systematic way, with the purpose of improving knowledge about the proposed theme.

For its operation, the following steps have been fulfilled: delimitation of the problem, collection, ob- 
servation, verification and understanding of the exposed elements [12]. After these steps, the collected studies have been critically evaluated, thus resulting in a reduction in the number of trials included in the final stage of the review.

The survey was conducted by searching online national and international scientific production between March/2015 to June/2016 in the Virtual Health Library (BVS) in databases: Latin American and Caribbean Sciences Health (LILACS) and the Nursing Database (BDENF). During the selection of scientific articles, the keywords "burnout" were used and "community health worker".

The inclusion criteria for the selection of the sample were as follows: articles indexed in databases, published in full in national and international journals; edited articles in Portuguese, English and/or Spanish.

There were no criteria for the period of publication of the work due to lack of studies related to this topic. Articles were excluded if they had repeated and that did not correspond to the main question of this research, as well as studies discoursing on the ACS work in other countries, because of the peculiarities of this professional practice integration in our country.
During the selection of studies, summaries of articles were analyzed, selected are those that interconnected the central theme "community health worker" aspects related to their health, work process and risks inherent in their profession.

After selection of the articles were analyzed 08 publications (04 are LILACS and 04 BDENF). After reading and analysis, it was found that 02 were not related to the topic of study. This study used only 06 publications.

The selected articles were analyzed in a critical and detailed manner in order to perform data collection that allows systematizing the findings and prepare the organization of information. For extraction of information from articles in the integrative review and to facilitate the structural visualization and logic of this study, there was the following scheme: title search, year, training of authors, type of study, objective of the study, results / conclusion.

\section{Results}

For better presentation and organization of the six selected articles, the picture was built below, for purposes of denoting basic and general characteristics of the studies. (Table 1)

Table 1. Items selected for the sample, João Pessoa, Brazil, 2016.

\begin{tabular}{|c|c|c|c|c|c|}
\hline $\mathbf{N}^{\circ}$ & Year & Authors & Title & Data Base & Modality \\
\hline 01 & 2011 & Santos, L. F. B; David, H. M. S. L. & $\begin{array}{l}\text { Perceptions of stress at work by } \\
\text { community health workers }\end{array}$ & BDENF & $\begin{array}{l}\text { A descriptive study of } \\
\text { qualitative approach. }\end{array}$ \\
\hline 02 & 2015 & $\begin{array}{l}\text { Jorge, J. C; Marques, A. L. N; } \\
\text { Cortez, R. M; Ferreira, M. B. G; } \\
\text { Haas, V. J; Simoes, A. L. A. }\end{array}$ & $\begin{array}{l}\text { Quality of life and stress of } \\
\text { community health agents of a } \\
\text { city in Minas Gerais }\end{array}$ & BDENF & $\begin{array}{l}\text { Sectional study with a } \\
\text { quantitative approach. }\end{array}$ \\
\hline 03 & 2014 & $\begin{array}{l}\text { Santos, I. E. R; Vargas, M. M; } \\
\text { Reis, F. P. }\end{array}$ & $\begin{array}{l}\text { Labor stressors of community } \\
\text { health workers }\end{array}$ & LILACS & $\begin{array}{l}\text { Inventory symptoms of } \\
\text { stress for adults Lipp (iSSI) }\end{array}$ \\
\hline 04 & 2012 & $\begin{array}{l}\text { Camelo, S. H. H; Galon, T; } \\
\text { Marziale, M. H. P. }\end{array}$ & $\begin{array}{l}\text { Illness forms the work of } \\
\text { community health workers and } \\
\text { management strategies }\end{array}$ & BDENF & Integrative review \\
\hline 05 & 2011 & $\begin{array}{l}\text { Maia, L. D. G; Silva, N. D; } \\
\text { Mendes, P. H. C. }\end{array}$ & $\begin{array}{l}\text { Burnout Syndrome in community } \\
\text { health agents: aspects of their } \\
\text { training and practice }\end{array}$ & LILACS & Literature revision \\
\hline 06 & 2009 & Wai, M. F. P; Carvalho, A. M. P. & $\begin{array}{l}\text { The work of community health } \\
\text { agent: overload factors and } \\
\text { coping strategies }\end{array}$ & BDENF & $\begin{array}{l}\text { Model Lazarus Folkman/ } \\
\text { descriptive and qualitative }\end{array}$ \\
\hline
\end{tabular}


With regard to the year of publication of selected articles were identified the years 2009, 2012, 2014 and 2015. In 2011 there were two articles published.

The items found are of national magazines, some international circulations, with a greater amount of journals associated with public universities and collective health and workers' health. The selected journals showed the purpose of the study clearly and easily understood and understanding to the reader. The purpose of the literature established the proposed action, to answer the central question of the study. The state of Rio de Janeiro presented three publications, the states of São Paulo, Santa Catarina and Minas Gerais identified an article, respectively.

With reference to the professions of the authors were part of these studies 19 authors, these eleven are nurses, an academic nursing, two doctors and an academic medicine, a physicist, a psychologist, a dentist and a management professional.

For a better understanding of the study analysis were developed two thematic categories: a) risk factors in the development of SB in ACS; b) coping strategies of stress of ACS.

\section{Discussion}

\section{A) Risk factors for the development of the SB in ACS}

CHWs are exposed to situations that require you skills that can be considered as risk factors for developing the SB. This reality of low recognition, bureaucracy, high intensity and pace, violence, and physical and mental overload are stress factors for ACS [13].

Given this reality the selected articles bring forms of illnesses by ACS. Article 1 provides low recognition, as well as the form of relationship with her superior. Besides being a factor that intervenes in labor productivity, as well as the ima- ge that the worker observes the work, the form of communication with superiors and professionals in the same position and also the people they watched. The ACS is seen as a little valued and recognized professional, although reference in the role of communication and coordination, as one of the responsible for the adhesion of the residents health practices that intended effect in that locality [13].

The recognition of the ACS function by the responsible manager is key to professional success and a good mood at work. Regarding this dimension, it is appropriate to emphasize the need for positive feedback on the working relationship between the manager and the ACS, to enable the UBS responsible monitor the activities undertaken by the agent, professional advancement and interference in workers' quality of life [14].

Management issues in Article 3 show evidence that, when the head of UBS is not prepared for the position he holds and does not consider the value of the ACS activity, more than $70 \%$ of the agents consider this factor as stressful [15].

Some authors describe in Articles 2, 5 and 6 the many duties of the agents set up a contradiction of the work done and provided in the manuals and the ACS standards. The actions of some activities that, while not assigning ACS end up part of your reality. Moreover, an emotional charge with the situation of extreme poverty, disease, human degradation observed and experienced in the daily lives of agents [16].

Articles 1 and 2 indicate that over 55\% of the professionals recognize that accompany a number of family beyond the established, as well as the feeling of not being valued by the developed activity $(61.5 \%)$ are highly stressful elements. This finding tells that the idea that interpersonal conflicts at work are more stressful factors that bond with the family.

Organizational issues and poor reward method were considered as key element of the stress in- 
volved in the ACS quality of life, thus considerably more than the relationship with users [17]. Some researchers in Article 3 show that a high amount of activity can progressively generate emotional and physical exhaustion, decreasing energy and leading directly to the competence of activities, health and willingness worker [18].

The danger in the workplace creates a stress load and fear. In addition to suffering physical damage and moral, showing a risk to the welfare and health of the ACS. However, in Article 1 research, there are reports of some ACS, about the relationship of work stress and injury to health, some professionals prefer to deny this relationship, even giving indications that these situations of suffering at work were true [13].

So sign of stress among professional team family health in Article 3, ACS was considered the professional with the increased availability of having work-related stress. The main symptoms mentioned were: feeling of physical stress, muscle tension and insomnia. Psychological symptoms most mentioned in the study were: a sudden urge to start other activities, speak and think only in a particular subject. For some authors of articles 5 and 6, the stress on the work indicates burnout syndrome that describes the physical and mental exhaustion of the worker when the trader has more strategies to face stressful situation and problems in the workplace [19, 20, 21].

Lipp (2000) in his research emphasizes that the body tries to adapt seeking balance (homeostasis) internal, giving time for perception of corrosion of your energy and physical exhaustion, making the body fatigued from their adaptive power stocks. It was observed that the most prevalent physical manifestations are muscle tension (17.8\%), feeling of physical wear (15.5\%) and constant tiredness (12.9\%) [19].

Regarding the more chronic symptoms, predominantly psychological nature: insomnia (10.9\%), feelings of excessive fatigue (9.4\%) and irritability
(7.2\%). Because $61.4 \%$ of the sample has shown some stress in the phases, it is evident the need to identify stressors in each. Regarding the most obvious manifestations, preponderates the natural phenomena: insomnia (10.9\%), perception of exhaustion (9.4\%) and excitability (7.2\%) [22].

Some situations arising from the work developed by the ACS end up causing stress situation. The assignment to be the communication link between the community residents and service, developed by ACS to be resident of the community and have roughly the same lifestyle, establishing a link between scientific knowledge and popular knowledge, without a hierarchy and assist community residents, there may be the appearance of mental and physical exhaustion [23].

There is a workload on these professionals, they are doubly charged, being a resident of the same community and the physical, social and emotional approach to the community, so that often the ACS to perform activities outside the time set for their assignments, surpassing the time given to its function and causing conditions to develop the labor STRESS [20, 24].

The ACS health status may also suffer psychological damage. The burnout and stress are elements that brings a number of threats to workers, affecting the quality of life, work productivity and can cause relationship difficulties with both team members family health, but also with the locals and reflection on the quality of care $[25,20,26]$.

The article 3, also refers to $58.5 \%$ of ACS mention that UBS physical part for conducting activities could be analyzed as a stressor, just as the equipment available was considered to 72.9 stressor \% of ACS [22]

The analysis of the items chosen in this study provided insight into how it is organized the activities of the ACS, leave them vulnerable to occupational diseases, both physical and psychic order, intervening in assistance to users of the service. Faced with illness factors at work, the ACS are unprotected, ha- 
ving to seek management means, in order to avoid damage to their quality of life [20].

\section{B) Coping stress of ACS}

With the objective of some articles, coping strategies used by ACS, the forms that used to deal with stress, difficulties and conflicting situations at work. The coping mechanisms analyzed in the study were: look adversity as a means of learning; Use of equilibrium; share with professionals and staff difficulties; see strategies for less emotional actions and more professional; create together with the coordinator of the family health strategy means for prevention and promotion of mental health of the worker; impose limits to residents attended; performing therapy; be aware that you cannot solve it alone; have a religion; believe in God and hold prayers; practice meditation; leisure activities; practice physical activity $[21,27]$.

Coping strategies are conceptualized as the ways people have found to deal with stressful situations on a daily basis. The worker develops some skills to cope and ease the difficulties in the work environment, in order to transform into a more productive and enjoyable activity [28].

The training strategies is interesting to prevent damage to the health of ACS and produce motivation, improving their job satisfaction. One of the alternatives most used by agents is to have emotional and social support to deal with the problems and difficulties, beyond the limits of personal life [29].

Some of the strategies are defined by Dejours (1993) as means necessary for agents developed to deal with the suffering experienced. Were analyzed in the studies the main alternatives used by the employee: working with uniform; have the playing time at work, use collective thoughts, seek emotional support in the family, religion and friends [2].

Carry out their activities with the uniform is evidenced in the study as a way to impose limits to residents of the assisted community, who want to abort the agent even when the ACS is not on your working hours [30].

In addition to making the use of compensation and positive comparison, see adversity as a means of learning, following its most professional activities and less emotional and with full awareness that it cannot solve everything alone, are alternatives for coping that are evidenced in the workplace [31].

It is essential to look for alternative ways to have a new look to the stressor, learn new skills and have new suction means. Conflicts regarding the thrill involve commitment to organize the emotional situation linked with stress, so professionals who use this means of coping to impose limit negative emotions and make it impossible that the negative emotions dominate [32].

Article 2 mainly brings physical activity and leisure activities and have positive thinking with stressful situations throughout the day to day. According to Telles and Pepper (2009), the means of taking the focus on the problem and have unrealistic thoughts also were the strategies most used by ACS. In addition, research refer to the ACS count on support mainly coming from co-workers. Also states that the use of the host can be adopted at UBS, as a means to help the ACS deal with the difficulties in the workplace [11].

The absence of social support presented in Articles 2 and 4, reveals how an element of stress from lack of support on the desktop, the agent can see, you have to launch own resources to face the stress and adversity of circumstances. Social support is interconnected with the engagement of the agent in proactive means of control, accounting for more than just emotional support [33].

The absence of such aid, takes the employee to use means of individual confrontations among which stand out driven by emotion, as the act of crying, which can demonstrate a state of exhaustion. The act of crying helps to reduce tension. Nevertheless, the individual may have feelings of powerlessness 
against you, and may develop depression or addiction to alcohol, drugs or drugs [21]. The use of antidepressants and anxiolytics were also identified in Article 2 as coping means for stressful situations in work activities [34].

The participation of the ACS in policy decision environments, such as health councils and conferences must result in the strengthening of better working conditions [35]. A good relationship of coexistence among team members determines the effectiveness of teamwork, but also create bonds between professionals and the organization of work [36].

Considering the mechanisms used by the agents to deal with different forms of chronic stressors present in the workplace. The act of performing physical activity releasing substance (endorphin) capable of producing welfare sensations and relaxation, have a balanced diet (healthy), able to nourish all the nutrients spent in stressful situations; relaxation techniques that reduce anxiety [37].

\section{Conclusion}

In the present study, we sought to analyze the research the risk factors for the development of burnout syndrome in this profession ACS, being a professional that deals daily with personal relationships and conflict management and needs. The physical and emotional closeness with the population served, and especially the macro-structural problems of the territory were analyzed as potential factors for the development of stress.

It is clear, that the forms of illness experienced by agents is difficult to change because the main risk factors are inherent in the duties and category work process. However, you can minimize them seeking coping strategies such as family, social and spiritual support, investment in motivation and safety at work, but there seems to be ignorance on the part of agents, as the activities that can be developed with the aim of reducing the stress that result from the work process.
Therefore, it is necessary that the risk factors that lead to disease and prevention methods are discussed with the agents in Introductory courses of Health and the multidisciplinary team of the Family Health Strategy, clarifying the duties and responsibility category avoiding overlapping activities and fostering understanding of the risks inherent in their work process and the limitations of their function with the purpose of preventing burnout.

Given this, it is necessary to greater interest of management to perform quality interventions from training process to the development of the work of the ACS and the ESF, since this profession is an essential element for achieving the principles and guidelines of Attention Basic in family care.

Therefore, this literary survey helped to identify the relationship between the Community Health Agent and SB, highlighting the risk factors and the main forms of coping this problem showing among other factors training and work process as influencing elements for development of the disease.

\section{References}

1. Brun P, Castagliuolo I, Di Leo V, Buda A, Pinzani M, Palù G, Martines D. Increased intestinal permeability in obese mice: new evidence in the pathogenesis of nonalcoholic steatohepatitis. American Journal of Physiology-Gastrointestinal and Liver Physiology. 2007 Feb 1; 292(2):G518-25. Available from: http:// ajpgi.physiology.org/content/292/2/G518.short

2. Dejours C, Abdoucheli E, Jayet C, Betiol MI. Psicodinâmica do trabalho: contribuições da escola dejouriana à análise da relação prazer, sofrimento e trabalho. São Paulo: Atlas; 1994.

3. Azambuja EP, Kerber NP, Kirchhof AL. A saúde do trabalhador na concepção de acadêmicos de enfermagem. Rev Esc Enferm USP. 2007; 41(3):355-62. Available from: http://repositorio.furg. br/handle/1/1163

4. Robazzi ML, Mauro MY, Secco IA, Dalri RD, Freitas FC, Terra FD, Silveira RC. Alterações na saúde decorrentes do excesso de trabalho entre trabalhadores da área de saúde. Rev. enferm. UERJ. 2012 Dec; 20(4):526-32. Available from: http://www. facenf.uerj.br/v20n4/v20n4a19.pdf

5. Dejours C. Banalizacao Da Injustica Social, a. FGV Editora; 1999. 
6. Benevides-Pereira AM. O estado da arte do Burnout no Brasil. Revista Eletrônica InterAção Psy. 2003 Aug 1; 1(1):4-11. Available from: http://tupi.fisica.ufmg.br/michel/docs/ Artigos e textos/Stress qualidade de vida/007\%20B $\% 20$ - $\% 20$ Burnout $\% 20-\% 20$ Diversos $\% 20$ artigos $\% 20-\% 20$ REVISTA\%20ELETR\%D4NICA.PDF\#page $=4$

7. Schaufeli WB, Leiter MP, Maslach C. Burnout: 35 years of research and practice. Career development international. 2009 Jun 19; 14(3):204-20. Available from: http://www.emeraldinsight.com/ doi/pdfplus/10.1108/13620430910966406

8. Silva JA, Dalmaso AS. O agente comunitário de saúde e suas atribuiçöes: os desafios para os processos de formaçäo de recursos humanos em saúde. Interface comun. saúde educ. 2002 Feb; 6(10):75-83. Available from: http://www.scielo.br/scielo. php?script=sci arttext\&pid=S1414-32832002000100007\&lng $=$ pt\&nrm=iso\&tlng=pt

9. Mascarenhas $\mathrm{CH}$, Prado FO, Fernandes $\mathrm{MH}$. Fatores associados à qualidade de vida de agentes comunitários de saúde. Ciênc Saúde Coletiva. 2013 May 1; 18(5):1375-86. Available from: http://search.proquest.com/openview/4f1941e093cd7792aa15 0b7def5c5d0a/1.pdf?pq-origsite $=$ gscholar $\&$ cbl $=2034998$

10. Resende MC, Azevedo EG, Lourenço LR, Faria LD, Alves NF, et al. Saúde mental e ansiedade em agentes comunitários que atuam em saúde da família em Uberlândia (MG, Brasil). Ciênc. saúde coletiva. 2011 Apr; 16(4):2115-22. Available from: http://www.scielo.br/scielo.php?script=sci arttext\&pid $=\mathrm{S} 1413-81232011000400011$

11. Telles H, Pimenta AM. Síndrome de Burnout em agentes comunitários de saúde e estratégias de enfrentamento. Saúde e Sociedade. 2009 Sep 1; 18(3):467-78. Available from: http:// www.revistas.usp.br/sausoc/article/view/29616/0

12. Mendes KD, Silveira RC, Galvão CM. Revisão integrativa: método de pesquisa para a incorporação de evidências na saúde e na enfermagem. Texto \& Contexto-Enfermagem. 2008; 17(4):758-64. Available from: http://www.producao.usp.br/ handle/BDPI/3509

13. Santos LF, David HM. Percepções do estresse no trabalho pelos agentes comunitários de saúde. Rev. enferm. UERJ. 2011 Mar; 19(1):52-7. Available from: http://www.facenf.uerj.br/v19n1/ v19n1a09.pdf

14. LentzRA, Costenaro RG, Gonçalves LH, Nassar SM. O profissional de enfermagem e a qualidade de vida: uma abordagem fundamentada nas dimensões propostas por Flanagan. Revista Latino-Americana de Enfermagem. 2000 Aug 1; 8(4):7-14

15. Jesus AS, Santos FP, Rodrigues VP, Nery AA, Machado JC, Couto TA. Atuação do agente comunitário de saúde: conhecimento de usuários. Rev. enferm. UERJ. 2014 Apr; 22(2):239-44. Available from: http://www.facenf.uerj.br/v22n2/v22n2a15.pdf
16. Durão AV, Morosini MV, Carvalho V. Os agentes comunitários de saúde e o conceito de comunidade na configuração de sua qualificação. Para além da comunidade: trabalho e qualificação dos agentes comunitários de saúde. Rio de Janeiro: EPSJV. 2011:119-60. Available from: http://www.fiocruz.br/media/ livro epsjv.pdf\#page $=119$

17. Vasconcellos ND, Costa-Val R. Avaliação da qualidade de vida dos agentes comunitários de saúde de Lagoa Santa-MG. Rev. APS. 2008 Jan; 11(1):17-28. Available from: http://www.ufjf.br/ nates/files/2009/12/017-028.pdf

18. Paschoal T, Tamayo Á. Validação da escala de estresse no trabalho. Estudos de psicologia. 2004 Jan; 9(1):45-52. Available from: http://www.scielo.br/pdf/\%0D/epsic/v9n1/22380.pdf

19. Novaes LM. Manual do inventário de sintomas de stress para adultos de Lipp. São Paulo: Casa do Psicólogo, 2000.

20. Camelo SH, Galon T, Marziale MH. Formas de adoecimento pelo trabalho dos agentes comunitários de saúde e estratégias de gerenciamento. Rev. enferm. UERJ. 2012 Dec; 20(1, n. esp):661-7. Available from: http://www.facenf.uerj.br/v20nesp1/ v20e1a19.pdf

21. de Lima Trindade L, Lautert L. Síndrome de Burnout entre os trabalhadores da Estratégia de Saúde da Família. Revista da Escola de Enfermagem da USP. 2010 Jun 1; 44(2):274-9. Available from: http://www.revistas.usp.br/reeusp/article/view/40536

22. Santos MD, Abalo JG. Síndrome de Burnout en médicos que trabajan en unidades de cuidados intensivos neonatales. Psicología y Salud. 2014 Jan 23; 15(1):25-32. Available from: http://revistas.uv.mx/index.php/psicysalud/article/view/816

23. Jorge JC, Marques AL, Côrtes RM, Ferreira MB, Haas VJ, Simões AL. Qualidade de vida e estresse de agentes comunitários de saúde de uma cidade do interior de Minas Gerais. Revista de Enfermagem e Atenção à Saúde. 2015 Jul 21; 4(1).

24. Kurogi MS. Qualidade de vida no trabalho e suas diversas abordagens. Revista de Ciências Gerenciais. 2015 Jul 17; 12(16):63-76. Available from: http://www.pgsskroton.com.br/ seer/index.php/rcger/article/view/2642

25. Martín MC, Fernández FB, Gómez RN, Martínez FC. Prevalencia y factores asociados al burnout en un área de salud. Atención primaria. 2001 Dec 31; 27(5):313-7. Available from: http://www. sciencedirect.com/science/article/pii/S0212656701793730

26. Kluthcovsky AC, Takayanagui AM, Santos CB, Kluthcovsky FA. Avaliação da qualidade de vida geral de agentes comunitários de saúde: a contribuição relativa das variáveis sociodemográficas e dos domínios da qualidade de vida. Rev. Psiquiatr. Rio Gd. Sul. 2007 Aug; 29(2):176-83. Available from: http://www.scielo.br/scielo.php?script=sci_arttext\&pid=S0101$81082007000200009 \& \operatorname{lng}=p t \& n r m=i s o \& t \operatorname{lng}=e n$

27. Barroso SM, Guerra AD. Burnout e qualidade de vida de agentes comunitários de saúde de Caetanópolis (MG). Cad. saúde colet.,(Rio J.). 2013 Sep; 21(3):338-45. Available from: http://www.scielo.br/scielo.php?script=sci arttext\&pid=S1414462X2013000300016 
28. Rosa AJ, Bonfanti $A L$, de Sousa Carvalho C. O sofrimento psíquico de agentes comunitários de saúde e suas relações com o trabalho. Saúde e Sociedade. 2012 Mar 1; 21(1):14152. Available from: http://www.revistas.usp.br/sausoc/article/ view/29825/0

29. Tinoco MM. A relação saúde/doença no processo de trabalho dos Agentes Comunitários de Saúde: uma revisão de literatura. 2015. Tese de Doutorado. Escola Nacional de Saúde Pública Sergio Arouca. Available from: http://arca.icict.fiocruz.br/ handle/icict/13214

30. Jardim TD, Lancman S. Aspectos subjetivos do morar e trabalhar na mesma comunidade: a realidade vivenciada pelo agente comunitário de saúde. Interface-Comunicação, Saúde, Educação. 2009; 13(28):123-35. Available from: http://www. producao.usp.br/handle/BDPI/9116

31. Ursine BL, Trelha CS, Nunes ED. O Agente Comunitário de Saúde na Estratégia de Saúde da Família: uma investigação das condições de trabalho e da qualidade de vida. Rev. Bras. Saude Ocup. 2010 Dec; 35(122). Available from: http:// www.scielo.br/scielo.php?script=sci arttext\&pid=S030376572010000200015\&lng=en\&nrm=iso\&tlng=pt

32. Martínez OF, Cabrera CH, Tapia AM, Suárez SM, del Río García BG. Burnout en médicos residentes que realizan guardias en un servicio de urgencias. emergencias. 2007; 19:116-21. Available from: http://residentsvergedelacinta.blogspot.es/img/burnout. $\underline{\mathrm{pdf}}$

33. Pinheiro FA, Tróccoli BT, Tamayo MR. Mensuração de coping no ambiente ocupacional. Psicologia: teoria e pesquisa. 2003 May; 19(2):153-8. Available from: http://www.scielo.br/pdf/\%0D/ ptp/v19n2/a07v19n2.pdf

34. Lopes CC, Ribeiro TP, Martinho NJ. Síndrome de Burnout e sua relação com a ausência de qualidade de vida no trabalho do enfermeiro. Enfermagem em Foco. 2012; 3(2). Available from: http://revista.portalcofen.gov.br/index.php/enfermagem/article/ view/264/0
35. Nogueira RP, Silva FB, Ramos ZD. Vinculação institucional de um trabalhador sui generis: o agente comunitário de saúde. 2000. Available from: http://repositorio.ipea.gov.br/ handle/11058/2371

36. de Araujo Lopes AC, Silva EE, da Silva Cruz M, Barbosa TS, Custódio EM. O trabalho comunitário sustentável: sua influência na qualidade de vida do trabalhador. Psicólogo inFormação. 2009 Apr 30; 11(11):56-80. Available from: http://pepsic.bvsalud.org/scielo.php?script=sci arttext\&pid $=$ =\$1415-88092007000100004

37. Souza WC, Silva AD. A influência de fatores de personalidade e de organização do trabalho no burnout em profissionais de saúde. Estud Psicol. 2002 Jan; 19(1):37-48. Available from: https://www.researchgate.net/profile/ Wilma Costa souza/publication/250050870 A influencia de fatores de personalidade e de organizacao do trabalho no burnout em profissionais de saude/ links/5407a3790cf2c48563b81a24.pdf
Publish in International Archives of Medicine

International Archives of Medicine is an open access journal publishing articles encompassing all aspects of medical science and clinical practice. IAM is considered a megajournal with independent sections on all areas of medicine. IAM is a really international journal with authors and board members from all around the world. The journal is widely indexed and classified Q2 in category Medicine. 